\title{
Twin Deficit Revisited: Evidence From India, Pakistan And Mexico
}

Kishore G. Kulkarni, (E-mail: kulkarnk@mscd.edu), Metropolitan State College of Denver, Erick Lee Erickson, (E-mail: ericksoe@ mscd.edu), Metropolitan State College of Denver.

\begin{abstract}
In recent years twin deficit has been a subject of investigation for several authors including Darrat (1988), Day (1998), Evans (1986). In the decade of 1980s when US deficits behaved much like twins rather than distant cousins, there was a great interest in further research. Several attempts have been made to explain the reasons of expected casuality between trade and budget deficits. This paper attempts to test this casuality for trade and budget deficits for the annual data of India, Pakistan and Mexico.
\end{abstract}

\section{Introduction}

$\mathrm{n}$ recent years the twin deficits has been a subject of investigation for Darrat (1988), Day (1998) and Evans

(1986) among others. The decade of 1980s when deficits in budget and trade in case of the US economy behaved more like twins rather than distant cousins, the interest in this topic increased further. However the evidence of twin deficits has not been observed as commonly as the identity of total expenditure and total income would suggest. Moreover the causality of relationship between these deficits is not always observed in any specific direction. However, when the volumes of these deficits are large, the probability of the relationship between them increases significantly.

In this paper we select countries that traditionally have observed large trade and budget

Readers with comments or questions are encouraged to contact the authors via email.

deficits to explore causality between large trade and budget deficits in recent years. The paper is divided into four sections. Section 1 describes the basic identity in international macroeconomics, which argues that the deficits should have a twin like relationship. It carries out related literature survey to bring out the importance of the problem. Section 2 describes the data from three countries and explains the evidence of twin deficits in India, Pakistan and Mexico. Annual data series for 30 years will be used because it is believed that effect of one deficit on the other is more significant in yearly data than in quarterly data. A summary of economic conditions in these countries is also undertaken in Section 2. Section 3 uses the Granger causality test and VAR technique to find out which deficit affects the other more significantly. Data are tested for stationarity and the regression results are presented. Section 4 serves as a summary and conclusion of the results.

\section{Section 1: Reasons for Existence of Twin Defi- cits}

In simple Keynesian terms the total expenditures of the economy are defined as $\mathrm{C}+\mathrm{I}+\mathrm{G}+\mathrm{X}$ $\mathrm{B} \mathrm{M}$ where $\mathrm{C}$ is the consumption on the final 
goods and services by the consumer sector, I is the investment of the producer sector which includes the expenditure on purchase of machinery tools and equipment, construction activities and an increase in stock of inventories, $G$ stands for the government expenditure on such activities as the welfare payments, defense, transportation etc., $\mathrm{X}$ is the value of nation' $\mathrm{s}$ exports of goods and services and $\mathrm{M}$ is the value of nation's imports of goods and services expressed in the domestic currency. The GDP (Y) of an economy can also be defined from sources side as equal to $\mathrm{C}+\mathrm{S}+$
Tx where $\mathrm{S}$ is the saving and Tx is the tax revenue of the government.

As it is elaborated in any macroeconomic textbook, (one is Kulkarni (1997, chapter 7)) the level of GDP at which the total expenditure is equal to total income, the equilibrium level of GDP is defined. In terms of Figure 1, it means that $\mathrm{Ye}$ is the equilibrium level of GDP where the 45-degree line and total expenditure line intersect. (For more information about the specific reasons for the shape of total expenditure line, please refer to Kulkarni (1997, chapter 7))

Figure 1

Keynesian Cross and Equilibrium Level of GDP

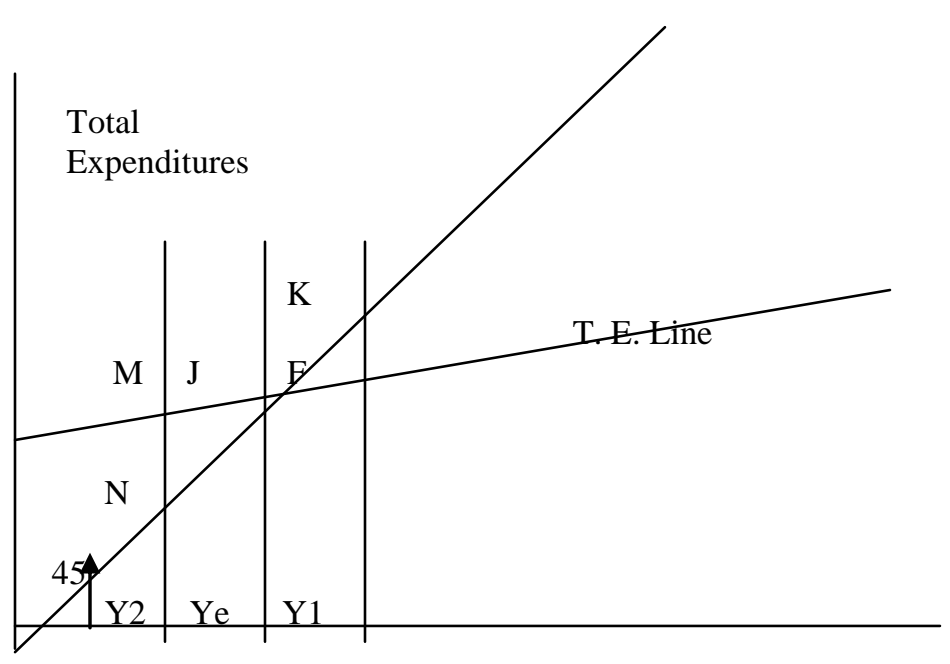

It can be effectively proved that economy will always produce equilibrium level of GDP. If economy produces any level of GDP that is higher than equilibrium, say Y1, then at Y1 GDP level, there is higher total income than total expenditure leading to excess supply of goods and services. Due to the excess supply, the prices in the economy will start declining, the expected profit rate or the marginal efficiency of capital will be become low, the investment will start declining, future output will decline, unemployment will go up and there will be overall recessionary force in this economy. This recessionary gap will be responsible for making the economy produce the future GDP at lower level than Y1.
Similarly if the economy by mistake produces GDP less than the equilibrium GDP, say Y2 then at Y2 level of GDP the total expenditure is higher than total income leading to excess demand for goods and services. This excess demand is responsible for higher prices leading to higher expected profit rate, higher investment, and higher future output. This condition of the economy because of higher prices is called "inflationary gap". Thus inflationary and recessionary gaps are responsible for making the economy produce no more and no less than the equilibrium level of GDP. 
Hence the economy sooner or later has total expenditure equal to total income leading us to write the following fundamental identity:

Total Expenditures $=$ Total Income

$\mathrm{C}+\mathrm{I}+\mathrm{G}+\mathrm{X}-\mathrm{M}=\mathrm{C}+\mathrm{S}+\mathrm{Tx}$

Canceling consumption on both sides of equation (1) and making rearrangement we get

$(\mathrm{I}-\mathrm{S})+(\mathrm{G}-\mathrm{Tx})=(\mathrm{M}-\mathrm{X})$

Assuming stability of the first term in equation (2), and recognizing that second term in it is the deficit on government's budget, and third term means the trade deficit, we can deduce that the two deficits would be always equal to each other. In fact if one goes up, then the other one would go up too and vice versa. This leads to the conclusion that these deficits act like twins, hence they are called, "Twin deficits".

Equation (2) also forms the basis for Alexander's famous Absorption Approach to the balance of payments. The original formation of this approach is found in Alexander (1952). According to absorption approach, the trade deficit is closely related to budget deficit. Hence any change in other economic variables, (say, for example, change in exchange rate) can bring about decline in trade deficit, only if it is associated with "austerity program" (meaning reduction in Government Expenditure) on the part of government. Thus success of exchange rate policy is dependent upon how strongly it is supported by the restrictive fiscal policy. More importantly, if trade balance defines the balance of payments (BOP), like it does in cases of underdeveloped countries where capital flows either are severely restricted or are of negligible volume, then BOP is in deficit as long as fiscal policy is of expansionary kind. This was also one of the important criticisms of traditional Keyensian economics which rarely paid attention to the trade balance effects of the expansionary fiscal policy. (For more information on this please see Kulkarni (1983).

The relevance of twin deficits can also be ex- plained in terms of IS-LM-BP curve analysis. Consider Figure 2, which shows the general equilibrium of the economy at point $\mathrm{J}$, where all three markets of the economy: money, goods or commodity, and foreign trade market are in equilibrium. The IS curve shows the locus of combinations of interest rate and GDP at which commodity market is in equilibrium. The commodity market equilibrium is defined by the equality of total expenditure $(\mathrm{C}+\mathrm{I}+\mathrm{G}+\mathrm{X}-\mathrm{M})$ and total income.

Similarly LM curve shows the combinations of interest rate and GDP at which money market is in equilibrium. As it is well known in macroeconomic literature, the money market equilibrium is defined by a point at which there is equality of quantity of money demanded and quantity of money supplied.

The combinations of interest rate and GDP that are needed to have $\mathrm{BOP}=0$, are traced by $\mathrm{BP}$ curve. BP curve slopes upwards because if current account and capital accounts are considered to be the main balances on BOP, then a higher GDP is responsible for higher imports which make current account deficit. To compensate this current account deficit by a capital account surplus (and to have BOP $=0$ ) we need to have higher interest rate which would be responsible for capital inflow. Hence higher GDP has to be associated with higher interest rate to have $\mathrm{BOP}=0$. The point at which all three (IS, LM, and BP) curves intersect, is a point where all three markets are in equilibrium simultaneously.

Now consider a change in fiscal policy. If government sector decides to adopt an expansionary fiscal policy (by raising the level of government expenditure, or by lowering the taxes) then first there is a budget deficit created and second this change in terms of Figure 2 is shown by a shift in the IS curve to the right. With the shift of IS curve to the right, the new equilibria of commodity and money market are achieved at point $\mathrm{K}$. At point $\mathrm{K}$ however, one can see that there is deficit in BOP. At point $\mathrm{K}$ deficit in balance of payment exists because at point $\mathrm{K}$, GDP is Y2 and interest rate is $\mathrm{r} 2$. With $\mathrm{r} 2$ interest rate, to have $\mathrm{BOP}=0$, the GDP required is $\mathrm{Y} 1$. This is evidenced by point $\mathrm{T}$ which is on BP curve with 
$\mathrm{r} 2$ interest rate. Hence at point $\mathrm{K}$ we have higher GDP than that is required for $\mathrm{BOP}=0$. Hence there is a deficit in BOP at point $\mathrm{K}$. Thus an expansionary fiscal policy that necessarily leads to deficit in the budget is also responsible for lead- ing to deficit in the trade. Hence there is another reason to believe that there will be an existence of twin deficits.

Figure 2

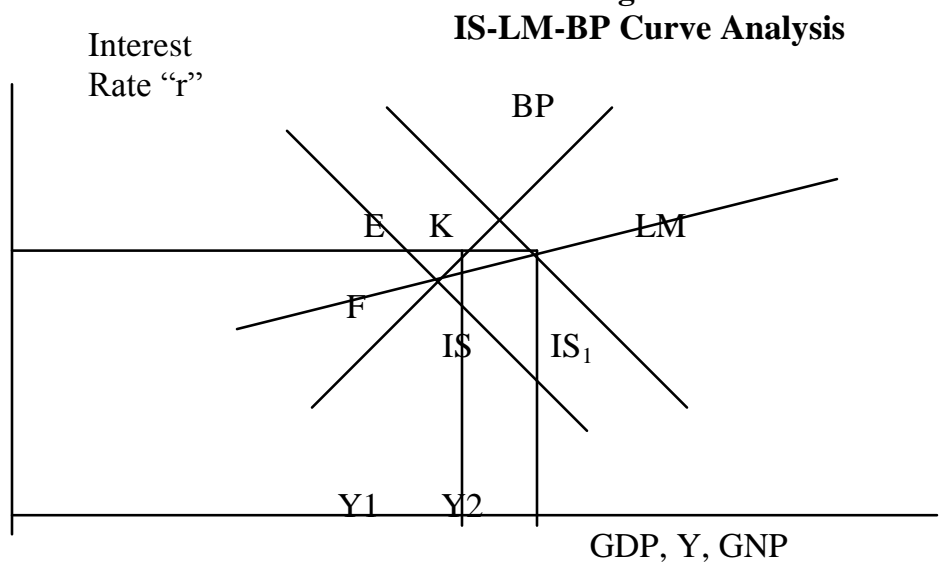

On empirical basis, twin deficit has been a favorite topic for researchers in recent times, as several authors have attempted to estimate the relationship between these two deficits. Rossensswerg and Tallman (1993) examine the causal relationship between budget and trade deficits for US by using five variable Vector Auto Regresssive (VAR) system. They use the variables of government purchases, government balance, trade balance, interest rate and exchange rate. Using the "Levels" of variables (as against the differences) they conclude that there is in fact an evidence of twin deficit phenomenon.

Mohammadi and Skaggs (1996) find the link between two deficits in US using five variables of real budget deficit, growth of M2 money supply, real current account balance, real income and real exchange rate. They test for multivariate cointegration and estimate vector error-correction (VER) model. They also examine effects of using different data transformations and of estimating the VAR model. When they use only two variables of trade and budget deficits, they find no evidence of co-integration in them. However when other variables are included in the model there is sufficient evidence of co-integration between two deficits. They also predict that a reduction of budget deficit by $\$ 86$ billion in the first quarter of 1990 would have reduced the current account deficit in the fourth quarter of 1992 by approximately $\$ 37$ billion. 
Table 1

India Pakistan Mexico Data: 1969-1997

\begin{tabular}{lcccccc}
$\mathbf{Y E A R}$ & $\underline{\mathbf{T D 1}}$ & $\underline{\mathbf{B D 1}}$ & $\underline{\mathbf{T D 2}}$ & $\underline{\mathbf{B D 2}}$ & $\underline{\mathbf{T D 3}}$ & $\underline{\mathbf{B D 3}}$ \\
\hline 1967 & 15.9 & 14.6 & 455 & 3857 & NA \\
1968 & 80.8 & 10.8 & 268 & 2991 & NA & NA \\
1969 & 37.68 & 10.2 & 322 & 2799 & NA & NA \\
1970 & 9.8 & 13.6 & 331.4 & 3945 & $\mathrm{NA}$ & NA \\
1971 & 38.6 & 16.0 & 209.0 & 3069 & NA & 4.78 \\
1972 & -22.1 & 21.8 & 16.36 & 2583 & NA & 16.71 \\
1973 & 30.6 & 17.0 & 16.50 & 4554 & NA & 27.41 \\
1974 & 120.3 & 23.6 & 614.8 & 5145 & NA & 31.23 \\
1975 & 286 & 32.0 & 980.9 & 11466 & NA & 42.04 \\
1976 & -787 & 36.9 & 1025 & 12239 & NA & 55.97 \\
1977 & 932 & 37.9 & 1366 & 12580 & NA & 55.97 \\
1978 & 884 & 50.8 & 1824 & 13247 & NA & 67.0 \\
1979 & 2222 & 63.0 & 2341 & 17997 & 2142 & 93.0 \\
1980 & 5644 & 88.6 & 2876 & 13394 & 3056 & 134 \\
1981 & 5711 & 87.3 & 2926 & 16138 & 3877 & 400 \\
1982 & 4820 & 107.3 & 3403 & 15351 & -7047 & 1170 \\
1983 & 4098 & 133.3 & 2715 & 24784 & -14105 & 1458 \\
1984 & 4025 & 175.8 & 3753 & 25928 & -13186 & 2131 \\
1985 & 5616 & 222.5 & 3230 & 33783 & -8399 & 3581 \\
1986 & 5438 & 272.0 & 2780 & 46917 & -5019 & 10341 \\
1987 & 5777 & 278.8 & 2316 & 48783 & -8786 & 27466 \\
1988 & 6581 & 320.6 & 2693 & 42426 & -2611 & 37843 \\
1989 & 6110 & 361.8 & 2571 & 56982 & -405 & 25589 \\
1990 & 5151 & 434.6 & 2714 & 46232 & 881 & 19436 \\
1991 & 2992 & 358.2 & 2262 & 77105 & 7279 & 1990 \\
1992 & 2911 & 399.0 & 2790 & 95418 & 15934 & -15959 \\
1993 & 2092 & 583.8 & 2552 & 118999 & 13481 & -4156 \\
1994 & 4150 & 567.3 & 2228 & 108591 & 18467 & 9927 \\
1995 & 6719 & 656.9 & 2878 & 89291 & -7089 & 10562 \\
1996 & 9462 & 648.4 & NA & NA & -6531 & 11479
\end{tabular}

Source: International Financial Statistics (IFS) Yearbook, International Monetary Fund, Washington D.C., 1998

TD1 = Trade deficit for India in billions of Rupees. BD1 = Budget Deficit for India in millions of U.S. dollars. BD2 = Budget deficit for Pakistan in millions of Rupees. TD2 = Trade deficit for Pakistan in millions of U.S. dollars. TD3 = Trade deficit in Mexico in millions of U.S. dollars. BD3 = Budget deficit in Mexico in millions of New Pesos.

Vamvoukas (1997) uses bi-variate and trivariate models to investigate the relationship between budget and trade deficits based on cointegration analysis and error correction model (ECM) strategy. He uses Greek annual data for period between 1948 and 1993. When he estimated bi-variate model he found no existence of co-integration between tow deficits but when he used GDP as the third variable he found strong and stable co-integration between two deficits. However his empirical evidence showed one-way causality from budget to trade deficit. In order to estimate the evidence of twin deficits using some developing countries ' data, we move to the next section.

Section 2: Evidence of Twin Deficits in India, 


\section{Pakistan and Mexico}

All three countries we selected in this study have a few common things in them: These are all developing countries, all have adopted a continuously expansionary fiscal policy in the period under study, and all have experienced trade deficits of different magnitude in this time period. Table 1 presents the annual data of these three countries for the time period between 1969 and 1996. By using simple regression model in first two equations and the Granger=s test (for more information on this technique, see Granger (1969) in the bibliography) in equations 3 and 4, we estimated the causality in the trade and budget deficits. Our results were as follows:

1) Table 2 lists the results for Mexico for the available data from 1979 to 1996 (sample size of 19). Four types of tests were performed in all three cases.

In their general forms, the estimated equations can be written as follows:

1) $\mathrm{TDi}=\mathrm{kBDi}$

where $\mathrm{i}=1,2,3$. TD and BD represent trade and budget deficits respectively, and $\mathrm{k}$ is the expected coefficient.

2) $\mathrm{BDi}=\mathrm{jBDi}$

where $\mathrm{i}=1,2,3 . \mathrm{j}$ is the expected coefficient.

3) $\operatorname{TDi}(\mathrm{t})=1 \mathrm{BDi}(\mathrm{t}-1)+\mathrm{mTDi}(\mathrm{t}-1)$

where $\mathrm{i}=1,2,3$. $\mathrm{L}$ and $\mathrm{m}$ are the expected coefficients, and (t) and (t-1) represent current and past time periods respectively.

4) $\operatorname{BDi}(\mathrm{t})=\mathrm{nBDi}(\mathrm{t}-1)+\mathrm{pTDi}(\mathrm{t}-1)$

where $\mathrm{I}=1,2,3$. (t) and (t-1) present the time periods.

It appears from the first set of results for the case of Mexico, that not only $\mathrm{R}$ square was extremely low (.087) but also there is no sign of causality from either direction between trade and budget deficits of the Mexican economy. Therefore we do not see unidirectional causality between trade and budget deficits in Mexico in the given time period, nor do we see any feedback as reported in the second set of results in Table 2. Thus in case of Mexico there is nom evidence of causality in twin deficits. Detail results of all regressions are reported in Table 2.

In case of India the results are vastly different than in Mexico. All tests have shown better results, and the R square is considerably higher than in case of Mexico. All the four equations' estimated results for India's case are listed in Table 3. While the simple regression analysis shows the relationship between trade and budget deficits, the Granger test indicates that the causality runs from budget deficit to trade deficit in case of India. As seen in equation 3 results in Table 3 , trade deficit is dependent upon budget deficit, the relationship that is expected by our macroeconomic analysis. Hence in case of India, we can witness with a great confidence internal an evidence of deficits acting more like twins rather than distant cousins.

2) In case of Pakistan as evidenced in four pages of Table 4, there is in fact an evidence of causality between budget and trade deficits, but the direction of causality runs exactly opposite of the Indian case. In Pakistan therefore, the relationship between the deficits runs form trade deficit to the budget deficit. The $\mathrm{R}$ square values are decent for all equations, and the relationships are justified, but the causality implies that the values of trade deficit affect the values of budget deficit. This is contrary to the traditional belief of the twin deficit idea, and exactly opposite of the results obtained for India. 
Table 2

Regression Results For Mexico: 1979-1996.

1) $\quad \mathrm{TD} 3=-.185 \mathrm{BD} 3$

$\mathrm{R}$ square $=.087$. Standard Error of the Estimate $=9137.4$

$\mathrm{T}$ statistic $=-1.27$.

1) $\quad \mathrm{BD} 3=-.471 \mathrm{TD} 3$

$\mathrm{R}$ square $=.087$. Standard Error of the estimate $=14591.9 \mathrm{~T}$ statistic $=-1.27$.

3) $\quad \mathrm{TD} 3(\mathrm{t})=.654 \mathrm{BD} 3(\mathrm{t}-1)-.0148 \mathrm{BD} 3(\mathrm{t}-1)$
(2.176)
$(-.115)$

$\mathrm{R}$ square $=.426, \quad$ Standard Error of the Estimate $=7701.64$

4)

$\mathrm{BD} 3(\mathrm{t})=-.008237 \mathrm{TD} 3(\mathrm{t}-1)+.794 \mathrm{BD} 3(\mathrm{t}-1)$

$(-.313)$

(4.805)

$\mathrm{R}$ square $=.634$ Standard error of the estimate $=9840.86$

Figures in the parenthesis represent $\mathrm{t}$ statistic of the estimated coefficient.

Table 3

Regression Results For India: 1979-1996

1) $\quad \mathrm{TD} 1=12.02 \mathrm{BD} 1$

$\mathrm{R}$ square $=.722$, Standard Error of the Estimate $=2195.75$

Durbin Watson statistic $=.363$, t statistic $=8.684$

2) $\mathrm{BD} 1=.006 \mathrm{TD} 1$

R square $=.722$, Standard Error of the Estimate $=155.1$

$\mathrm{T}$ statistic $=8.684$

3) $\quad \mathrm{TD} 1(\mathrm{t})=3.11 \mathrm{BD} 1(\mathrm{t}-1)+.87 \mathrm{TD} 1(\mathrm{t}-1)$

(1.14) (8.418)

$\mathrm{R}$ square $=.922$, Standard Error of the Estimate $=1207.5$

4) $\quad \mathrm{BD} 1(\mathrm{t})=1.045 \mathrm{BD} 1(\mathrm{t}-1)+.00034 \mathrm{TD} 1(\mathrm{t}-1)$

(18.96) (.916)

$\mathrm{R}$ square $=.98$ Standard Error of the Estimate $=43.5$

Figures in the parenthesis represent the t statistic of the estimated coefficient.

\section{Section 4: Summary and Conclusions}

In this paper our main objectives were to summarize the theoretical argument of twin deficit, review the existing literature, and apply the twin deficit idea to the three country data to test for empirical evidence. It was interesting to see that in case of Mexico there is no evidence of twin deficits occurring because of one another. In fact there was no evidence of causality running in either direction. One reason for this could be that the budget deficit and trade deficit values for Mexico have fluctuated very wildly and there were some problems in getting a long run data for Mexican economy.
In case of India there was a strong evidence of twin deficits. Moreover as expected by textbook explanation there was a reason to believe that budget deficits created trade deficits. Hence the traditional theory works efficiently in case of India. But the positive results of India were discredited by the experience of Pakistan in whose case we find that twin deficits existed, but the causality ran in an exactly opposite direction than in Indian case. In Pakistan therefore there is an evidence of trade deficits creating the budget deficits. With three country cases showing different evidences, the twin deficit idea has a little or no evidence in this time period. 
Table 4

Regrssion Results For Pakistan: 1979-1996.

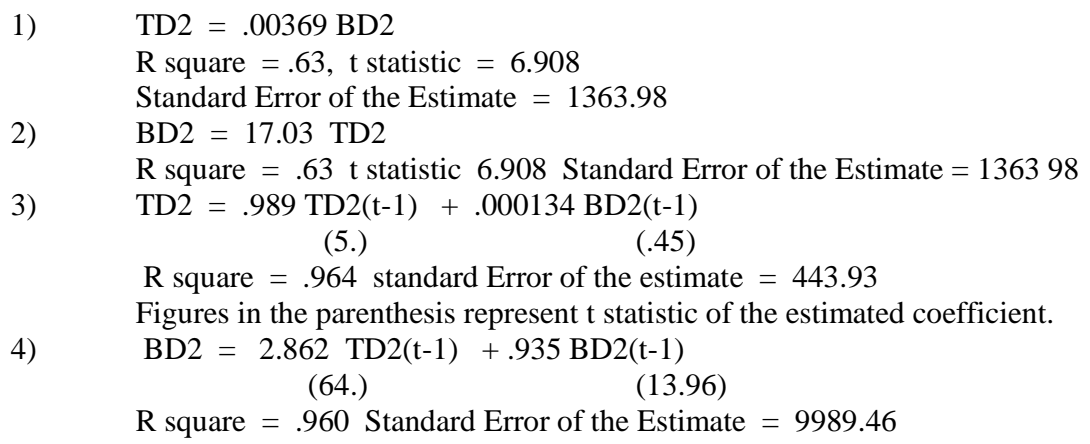

Figures in the parenthesis represent $t$ statistic of the estimated coefficient.

\section{Suggestions For Future Research}

There is a wide possibility of getting more relevant results for other countries' data using the same econometric technique as this paper has done. Not only can other countries' data be used but also other time periods can be tested. We suggest that readers use this topic for their research.

\section{Bibliography and References}

1. Abel, John D., "Twin Deficits During the 1980s: An Empirical Investigation", Journal of Macroeconomics, Winter 1990, pp. 81-96.

2. Alexander, Sydney, "Effects of Devaluation on a Trade Balance", IMF Staff Papers, 1952, pp. 263-278.

3. Darrat, Ali F., "Have Large Budget Deficits Caused Rising Trade Deficits?", Southern Economic Journal,_April 1988, pp. 879-87.

4. Day, Edward A., "Twin Deficits Revisited", Paper presented in Southern Economic Association meeting, November 1998, pp. 1-15.

5. Dewald, William G. and Ulan, Michael, "The Twin Deficit Illusion", Cato Journal, Winter 1990, pp. 689-707.

6. Enders, Walter and Bong-Soo Lee, "Current Account and Budget Deficits: Twins or Distant
Cousins?", Review of Economics and Statistics, August 1990, pp. 373-81.

7. Granger, C. W. J., "Investigating Casual Relations by Econometric Models and Cross Spectral Methods", Econometrica, July 1969, pp. 424-438.

8. Kawai, Masahiroa and Maccini, Louis J., "Twin Deficits verses Unpleasant Fiscal Arithmatic In a Small Open Economy", Journal of Money Credit and Banking, August 1995, pp. 639-658.

9. Kulkarni, Kishore, "First Principles of MacroMonetary Theory", Third Edition, Kendall/Hunt Publishing Company, Dubuque, Iowa, 1997.

10. Miller, Stephen and Russek Frank S., "Are the Deficits Really Related?", Contemporary Policy Issues, October 1989, pp.91-115.

11. Mohammadi Hasan and Skaggs Neil T., "US Fiscal Policy and Trade Deficits: A Broad Perspective", Southern Economic Journal, Vol. 62, No. 3, January 1996.

12. Rosensweig, Jeffrey and Tallman, Ellis W. "Fiscal Policy and Trade Adjustment: Are the Deficits Really Twins?", Economic Inquiry, October 1993, pp. 580-594.

13. Vamvoukas G. A., "Have Large Budget Deficits Caused Increasing Trade Deficits?: Evidence From A Developing Country", Atlantic Economic Journal, Vol. 25, No. 1, March 1997. 
Table 1

India Pakistan Mexico Data: 1969-1997

$\underline{\text { YEAR }}$

1967

1968

\begin{tabular}{r} 
TD1 \\
\hline 15.9 \\
80.8
\end{tabular}

$\frac{\text { BD1 }}{14.6}$

10.8

$\underline{\text { TD2 }}$

455

268
BD2

2991 $\underline{\text { TD3 }}$

NA

NA $\underline{\text { BD3 }}$

NA

NA 


$\begin{array}{rr}1969 & 37.68 \\ 1970 & 9.8 \\ 1971 & 38.6 \\ 1972 & -22.1 \\ 1973 & 30.6 \\ 1974 & 120.3 \\ 1975 & 286 \\ 1976 & -787 \\ 1977 & 932 \\ 1978 & 884 \\ 1979 & 2222 \\ 1980 & 5644 \\ 1981 & 5711 \\ 1982 & 4820 \\ 1983 & 4098 \\ 1984 & 4025 \\ 1985 & 5616 \\ 1986 & 5438 \\ 1987 & 5777 \\ 1988 & 6581 \\ 1989 & 6110 \\ 1990 & 5151 \\ 1991 & 2992 \\ 1992 & 2911 \\ 1993 & 2092 \\ 1994 & 4150 \\ 1995 & 6719 \\ 1996 & 9462\end{array}$

\section{2}

13.6

16.0

21.8

17.0

23.6

32.0

36.9

37.9

50.8

63.0

88.6

87.3

107.3

133.3

175.8

222.5

272.0

278.8

320.6

361.8

434.6

358.2

399.0

583.8

567.3

656.9

648.4
Volume 17, Number 2

$322 \quad 2799$

$331.4 \quad 3945$

$209.0 \quad 3069$

$16.36 \quad 2583$

$16.50 \quad 4554$

$614.8 \quad 5145$

$980.9 \quad 11466$

$1025 \quad 12239$

$1366 \quad 12580$

$1824 \quad 13247$

$2341 \quad 17997$

$2876 \quad 13394$

$2926 \quad 16138$

$3403 \quad 15351$

$2715 \quad 24784$

$3753 \quad 25928$

$3230 \quad 33783$

$2780 \quad 46917$

$2316 \quad 48783$

$2693 \quad 42426$

$2571 \quad 56982$

$2714 \quad 46232$

$2262 \quad 77105$

$2790 \quad 95418$

$2552 \quad 118999$

$2228 \quad 108591$

$2878 \quad 89291$

NA NA

$\begin{array}{rl}\text { NA } & \text { NA } \\ \text { NA } & \text { NA } \\ \text { NA } & 4.78 \\ \text { NA } & 16.71 \\ \text { NA } & 27.41 \\ \text { NA } & 31.23 \\ \text { NA } & 42.04 \\ \text { NA } & 55.97 \\ \text { NA } & 55.97 \\ \text { NA } & 67.0 \\ 2142 & 93.0 \\ 3056 & 134 \\ 3877 & 400 \\ -7047 & 1170 \\ -14105 & 1458 \\ -13186 & 2131 \\ -8399 & 3581 \\ -5019 & 10341 \\ -8786 & 27466 \\ -2611 & 37843 \\ -405 & 25589 \\ 881 & 19436 \\ 7279 & 1990 \\ 15934 & -15959 \\ 13481 & -4156 \\ 18467 & 9927 \\ -7089 & 10562 \\ -6531 & 11479\end{array}$

Source: International Financial Statistics (IFS) Yearbook, International Monetary Fund, Washington D.C., 1998

TD1 = Trade deficit for India in billions of Rupees. BD1 = Budget Deficit for India in millions of U.S. dollars. BD2 = Budget deficit for Pakistan in millions of Rupees. TD2 = Trade deficit for Pakistan in millions of U.S. dollars. TD3 $=$ Trade deficit in Mexico in millions of U.S. dollars. BD3 $=$ Budget deficit in Mexico in millions of New Pesos.

Table 2

Regression Results For Mexico: 1979-1996.

1) $\quad \mathrm{TD} 3=-.185 \mathrm{BD} 3$

R square $=.087$. Standard Error of the Estimate $=9137.4$

T statistic $=-1.27$.

2) $\quad \mathrm{BD} 3=-.471 \mathrm{TD} 3$

$\mathrm{R}$ square $=.087$. Standard Error of the estimate $=14591.9 \mathrm{~T}$ statistic $=-1.27$.

3) $\quad \mathrm{TD} 3(\mathrm{t})=.654 \mathrm{BD} 3(\mathrm{t}-1)-.0148 \mathrm{BD} 3(\mathrm{t}-1)$

$$
\text { (2.176) (-.115) }
$$

4) $\quad \mathrm{BD} 3(\mathrm{t})=-.008237 \mathrm{TD} 3(\mathrm{t}-1)+.794 \mathrm{BD} 3(\mathrm{t}-1)$

$\mathrm{BD} 3(\mathrm{t})=-.008237 \mathrm{(-.313)}(4.805)$

R square $=.634$ Standard error of the estimate $=9840.86$

Figures in the parenthesis represent t statistic of the estimated coefficient. 
Table 3

Regression Results For India: 1979-1996

1) $\quad \mathrm{TD} 1=12.02 \mathrm{BD} 1$

$\mathrm{R}$ square $=.722$, Standard Error of the Estimate $=2195.75$

Durbin Watson statistic $=.363$, t statistic $=8.684$

2) $\mathrm{BD} 1=.006 \mathrm{TD} 1$

$\mathrm{R}$ square $=.722$, Standard Error of the Estimate $=155.1$

T statistic $=8.684$

3) $\quad \mathrm{TD} 1(\mathrm{t})=3.11 \mathrm{BD} 1(\mathrm{t}-1)+.87 \mathrm{TD} 1(\mathrm{t}-1)$

(1.14) (8.418)

4) $\quad \mathrm{BD} 1(\mathrm{t})=1.045 \mathrm{BD} 1(\mathrm{t}-1)+.00034 \mathrm{TD} 1(\mathrm{t}-1)$

(18.96) (.916)

R square $=.98$ Standard Error of the Estimate $=43.5$

Figures in the parenthesis represent the $t$ statistic of the estimated coefficient.

Table 4

Regrssion Results For Pakistan: 1979-1996.

1) $\quad \mathrm{TD} 2=.00369 \mathrm{BD} 2$

$\mathrm{R}$ square $=.63, \mathrm{t}$ statistic $=6.908$

Standard Error of the Estimate $=1363.98$

2) $\quad \mathrm{BD} 2=17.03 \mathrm{TD} 2$

R square $=.63 \mathrm{t}$ statistic 6.908 Standard Error of the Estimate $=136398$

3) $\quad \mathrm{TD} 2=.989 \mathrm{TD} 2(\mathrm{t}-1)+.000134 \mathrm{BD} 2(\mathrm{t}-1)$

(5.) (.45)

$\mathrm{R}$ square $=.964$ standard Error of the estimate $=443.93$

Figures in the parenthesis represent $t$ statistic of the estimated coefficient.

4) $\quad \mathrm{BD} 2=2.862 \mathrm{TD} 2(\mathrm{t}-1)+.935 \mathrm{BD} 2(\mathrm{t}-1)$

(64.)

(13.96)

$\mathrm{R}$ square $=.960$ Standard Error of the Estimate $=9989.46$

Figures in the parenthesis represent $t$ statistic of the estimated coefficient. 